\title{
PENGARUH PRODUK DOMESTIK REGIONAL BRUTO (PDRB) DAN TINGKAT PENGANGGURAN TERBUKA TERHADAP INDEKS PEMBANGUNAN MANUSIA DI KABUPATEN LANGKAT
}

\author{
Mariana Naibaho ${ }^{1}$, Ulya Nabila ${ }^{2}$ \\ Jl. Prof. Dr. Syarief Thayeb, Meurandeh, Langsa Lama \\ Matematika, Fakultas Teknik, Universitas Samudra \\ Email: ${ }^{1}$ naibahomariana00@gmail.com, ${ }^{2}$ ulya.nabilla@unsam.ac.id
}

\begin{abstract}
ABSTRAK
Indeks Pembangunan Manusia (IPM) merupakan indikator penting untuk mengukur keberhasilan dalam upaya membangun kualitas hidup manusia. IPM dapat menentukan peringkat atau level pembangunan suatu wilayah/negara. Penelitan ini bertujuan untuk mengetahui pengaruh PDRB dan Tingkat Pengangguran Terbuka terhadap di Kabupaten Langkat. Adapun metode penelitian yang digunakan adalah metode kuantitatif dengan pendekatan deskriptif. Teknik analisis data menggunakan model regresi linier berganda yang didukung dengan uji asumsi klasik. Penelitian ini menggunakan data sekunder yang diperoleh dari Kantor BAPPEDA Langkat. Variabel Produk Domestik Regional Bruto (PDRB) berpengaruh negatif dan signifikan terhadap IPM di Kabupaten Langkat. Variabel Tingkat Pengangguran Terbuka berpengaruh negatif dan signifikan terhadap IPM di Kabupaten Langkat. Variabel Produk Domestik Regioanl Bruto (PDRB) dan Tingkat Pengangguran Terbuka secara bersama-sama berpengaruh signifikan terhadap IPM di Kabupaten Langkat. Sehingga dapat dikatakan bahwa PDRB salah satu penyebab kenaikan IPM di Kabupaten Langkat. Tingkat pengangguran terbuka adalah salah satu penyebab menurunnya IPM di Kabupaten Langkat. Dari hasil uji signifikan parsial variabel PDRB maka di dapat thitung sebesar 84,217> 1,720 dari $t_{\text {tabel }}$ hal ini menunjukkan bahwa variabel PDRB berpengaruh positif dan signifikan terhadap IPM di Kabupaten Langkat. Sedangkan untuk variabel tingkat pengangguran terbuka di dapat dengan nilai $t_{\text {hitung }}$ sebesar 1,725> 1,720 dari tabel hal ini menunjukkan variabel tingkat pengangguran terbuka berpengaruh negatif dan signifikan terhadap IPM di Kabupaten Langkat. Dari hasil uji signifikan simultan, maka di dapat nilai $\mathrm{f}_{\text {hitung }}$ sebesar 20,580>0.02 dari $\mathrm{f}_{\text {tabel }}$ dan juga dapat dilihat nilai probabilitas lebih kecil dari tingkat signifikan $(\alpha) 5 \%$ atau $0,000000<0,05$ maka dapat diambil kesimpulan bahwa PDRB dan tingkat pengangguran terbuka secara bersama-sama mempengaruhi IPM di Kabupaten Langkat.
\end{abstract}

Kata Kunci: Indeks Pembangunan Manusia, PDRB, Tingkat Pengangguran Terbuka, Regresi Berganda

\begin{abstract}
IPM is an important indicator to measure success in efforts to build the quality of human life. HDI can determine the ranking or level of development of a region/country. This study aims to determine the effect of GDP and the Open Unemployment Rate in Langkat Regency. The research method used is a quantitative method with a descriptive approach. The data analysis technique used multiple linear regression model supported by classical assumption test. This study uses secondary data obtained from the Langkat BAPPEDA Office. Variable Gross Regional Domestic Product (GRDP) has a negative and significant effect on HDI in Langkat Regency. The Open Unemployment Rate variable has a negative and significant effect on HDI in Langkat Regency. The variables of the Gross Regional Domestic Product (GRDP) and the Open Unemployment Rate together have a significant effect on the HDI in Langkat Regency. So it can be said that GRDP is one of the causes of the increase in HDI in Langkat Regency. The open unemployment rate is one of the causes of the decline in HDI in Langkat Regency. From the results of the partial significant test of the GRDP variable, tcount is 84,217> 1,720 from ttable, this indicates that the GRDP variable has a positive and significant effect on HDI in Langkat Regency. Meanwhile, the open unemployment rate variable is obtained with a tcount of $1.725>1.720$ from ttable, this shows that the open unemployment rate variable has a negative and significant effect on HDI in Langkat Regency. From the results of the simultaneous significant test, the fcount value of 20.580>0.02 from ftable can be seen and it can also be seen that the probability value is smaller than the significant level $(\alpha) 5 \%$ or $0.000000<0.05$, so it can be concluded that the GDP and the unemployment rate open jointly affect the HDI in Langkat Regency
\end{abstract}

Keywords: Human Development Index, GRDP, Open Unemployment Rate, Multiple Regression 


\section{Gamma-Pi: Jurnal Matematika dan Terapan}

Volume 3 Nomor 2 Desember 2021

\section{PENDAHULUAN}

Pembangunan secara tradisional dapat diartikan sebagai kapasitas dari sebuah perekonomian nasional yang kondisi ekonomi wilayah awalnya kurang lebih bersifat statis dalam kurun waktu yang cukup lama menuju peningkatan pendapatan nasional bruto atau GNI (gross national income) tahunan. Pembangunan ekonomi juga dapat diartikan sebagai suatu proses yang menyebabkan pendapatan perkapita penduduk suatu negara meningkat secara berkelanjutan dalam jangka panjang. Pada hakikatnya, pembangunan harus mencerminkan perubahan total dari suatu masyarakat atau penyesuaian sistem sosial secara keseluruhan tanpa mengabaikan keragaman kebutuhan dasar dan keinginan individu maupun kelompok-kelompok sosial yang ada didalamnya. Pembangunan memiliki tujuan akhir yaitu bergerak maju menuju kondisi kehidupan yang lebih baik (Imsar,2018).

Faktor sosial ekonomi tersebut diantaranya investasi sumber daya manusia, produk domestik regional bruto, pendapatan perkapita, kemiskinan dan pengangguran. Indeks Pembangunan Manusia (IPM) merupakan parameter yang sangat penting dalam melihat keberhasilan negara sebagai usaha membangun kualitas taraf hidup penduduk/ masyarakat pada suatu kabupaten/kota. Produk Domestik Regional Bruto (PDRB) adalah jumlah nilai tambah bruto yang timbul dari seluruh sektor perekonomian di daerah tersebut. Tingkat Pengangguran Tebuka adalah persentase jumlah pengangguran terhadap jumlah angkatan kerja (Kairupan,2013).

Pertumbuhan ekonomi berarti perkembangan kegiatan dalam perekonomian yang menyebabkan barang dan jasa yang diproduksi dalam masyarakat bertambah sehingga tingkat pendapatan juga mengalami kenaikan dan kemakmuran masyarakat juga akan meningkat. Pertumbuhan ekonomi suatu daerah dapat ditunjukkan dengan kenaikan Produk Domestik Regional Bruto (PDRB). Dalam rangka mengacu pertumbuhan ekonomi perlu dan harus memperhatikan aspek pembangunan manusia, termasuk dalam konteks ekonomi daerah, karena dengan modal manusia yang berkualitas, kinerja ekonomi di yakini juga akan lebih baik (Nurcholis, 2014).

Adapun metode yang digunakan dalam penelitian ini adalah regresi linier berganda. Analisis regresi merupakan analisis statistika yang digunakan untuk mengetahui hubungan antara variabel dependen dengan variabel independen.
Apabila hanya terdapat satu variabel dependen dan satu variabel independen disebut analisis regresi sederhana, sedangkan apabila terdapat beberapa variabel independen disebut analisis regresi ganda (Nirmata,2012).

Berdasarkan rumusan masalah diatas maka tujuan penelitian dalam penelitian ini adalah sebagi berikut:

1. Untuk mengetahui pengaruh PDRB terhadap IPM Di Kabupaten Langkat.

2. Untuk mengetahui pengaruh Tingkat Pengangguran Terbuka terhadap IPM Di Kabupaten Langkat.

3. Untuk mengetahui pengaruh PDRB dan Tingkat Pengangguran Terbuka terhadap IPM di Kabupaten Langkat.

\section{METODE PENELITIAN}

Metode pengolahan data menggunakan metode regresi linier berganda. Analisis data dalam penelitian ini menggunakan pendekatan kuantitatif deskriptif yang digunakan untuk menggambarkan kondisi PDRB, dan Tingkat Pengangguran Terbuka terhadap IPM di Kabupaten Langkat. Penelitian ini bertujuan untuk melihat pengaruh hubungan antara variabel independen terhadap variabel dependen. Variabel dependen yaitu pengaruh PDRB dan Tingkat Pengangguran Terbuka terhadap IPM di Kabupaten Langkat.

\subsection{Teknik Analisis Data}

\subsubsection{Uji Asumsi Klasik} a. Uji Normalitas

Uji Normalitas bertujuan untuk mengetahui normal atau tidaknya suatu distribusi data. Pada dasarnya uji normalitas membandingkan antara data yang kita miliki dengan berdistribusi normal yang dimiliki mean dan standar deviasi yang sama dengan data kita. Uji Normalitas dapat dilakukan dengan menggunakan SPSS yaitu dengan Normal QQ Plot.

\section{b. Uji Multikolonearitas}

Uji multikolinearitas dilakukan bertujuan untuk menguji model regresi bila ditemukan adanya korelasi antara variabel independen. Berdasarkan hasil analisis, jika variabel-variabel independen memiliki nilai toleransi lebih dari $10 \%$ dan memiliki nilai Variance Inflation Factor VIF > 10, maka model regresi tersebut bebas dari masalah multikoleniaritas.

\section{c. Uji Autokorelasi}

Uji Autokorelasi bertujuan untuk menguji apakah dalam model regresi linear ada kolerasi antara kesalahan pengganggu (disturbance term) 


\section{Gamma-Pi: Jurnal Matematika dan Terapan}

Volume 3 Nomor 2 Desember 2021

pada perode $\mathrm{t}$ dan kesalahan pengganggu pada perode sebelumnya ( $\mathrm{t}-1)$. Durbin-Watson dapat dilihat pada tabel Model Summary. Autokorelasi terjadi jika nilai Durbin-Watson tidak berada diantara dua sampai dengan 4-du.

\section{d. Uji Heteroskedastisitas}

Uji heteroskedastisitas bertujuan untuk menguji apakah model regersi terjadi ketidaksamaan variabel dari residual satu pengamatan ke pengamatan lain. Model regresi yang baik adalah tidak terjadinya heteroskedetisitas.

\subsubsection{Uji Hipotesis}

\section{a. Estimasi Model Regresi}

Analisis data dalam penelitian ini menggunakan pendekatan kuantitatif deskriptif yang digunakan untuk menggambarkan kondisi PDRB, dan Tingkat Pengangguran Terbuka terhadap IPM di Kabupaten Langkat. Penelitian ini bertujuan untuk melihat pengaruh hubungan antara variabel independen terhadap variabel dependen. Variabel dependen yaitu pengaruh PDRB dan Tingkat Pengangguran Terbuka terhadap IPM di Kabupaten Langkat. Untuk menguji kebenaran hipotesis yang diajukan, maka model yang digunakan adalah model regresi linear berganda (Nirmala, 2012).

$$
\text { Model yang digunakan dapat }
$$

diformulasikan sebagai berikut :

$$
\mathrm{Y}=\mathrm{a}+\mathrm{b}_{1} \mathrm{X}_{1}-\mathrm{b}_{2} \mathrm{X}_{2}
$$

Dimana :

$\mathrm{Y}=\mathrm{IPM}$

$\mathrm{X}_{1}=\mathrm{PDRB}$

$\mathrm{X}_{2}=$ Tingkat Pengangguran Terbuka

$\mathrm{a}=$ Konstanta

$b_{1} b_{2}=$ Koefisien Regresi

\section{b. Uji t-Statistik}

Pengujian ini berfungsi untuk mengetahui tentang pengaruh dari masingmasing variabel bebas terhadap variabel terikat apakah signifikan atau tidak. Pada pengujian kemudian akan dibandingkan nilai dari $t_{\text {hitung }}$ dengan $t_{\text {tabel }}$ pada derajat keyakinan yang digunakan dalam penelitian.

Menguji pengaruh nilai PDRB dan pengangguran terhadap IPM Kabupaten Langkat.

1. Rumusan Hipotesis

$\mathrm{H}_{0}: \beta \mathrm{I}=0$, artinya secara parsial, PDRB dan

Tingat Pengangguran Terbuka berpengaruh signifikan terhadap IPM di Kabupaten Langkat.

H1 : $\beta \mathrm{I}>0$, artinya secara parasial PDRB dan Tingkat Pengangguran Terbuka tidak berpengaruh signifikan terhadap IPM di Kabupaten Langkat.

2. Menentukan taraf nyata $\alpha=5 \%$, derajat kebebasan $\mathrm{df}=(\mathrm{n}-\mathrm{k})$

3. Criteria Pengujian

$\mathrm{H}_{0}$ diterima jika : $\mathrm{t}_{\text {hitung }}<\mathrm{t}_{\text {tabel }}$

$\mathrm{H}_{0}$ ditolak jika : $\mathrm{t}_{\text {hitung }}>\mathrm{t}_{\text {tabel }}$

Bila didapat nilai $t_{\text {hitung }}<\mathrm{t}_{\text {tabel }}$ maka $\mathrm{H}_{0}$ diterima dan $\mathrm{H}_{1}$ ditolak artinya variabel PDRB dan pengangguran tidak berpengaruh positif terhadap IPM Kabupaten Langkat, dan bila di dapat nilai $t_{\text {hitung }}>\mathrm{t}_{\text {tabel }} \mathrm{H}_{0}$ ditolak maka $\mathrm{H}_{1}$ diterima artinya PDRB dan pengangguran berpengaruh signifikan terhadap IPM Kabupaten Langkat.

\section{c. Uji F-Statistik}

Uji F-statistik dilakukan guna mengetahui koefisien yang diregresi signifikan atau tidak secara bersamaan. Jika $F_{\text {hitung }}>F_{\text {tabel }}$ maka $\mathrm{H}_{0}$ ditolak dan $\mathrm{H}_{1}$ diterima. Jika $\mathrm{H}_{0}$ ditolak, maka ini menunjukkan bahwa paling tidak ada satu variabel bebas yang signifikan secara statistic berpengaruh terhadap variabel tak bebas atau variabel terikat. Sedangkan jika $\mathrm{H}_{0}$ diterima, maka tidak ada satupun variabel bebas yang berpengaruh nyata terhadap variabel tak bebas secara statistik.Kabupaten Langkat. Untuk menguji kebenaran hipotesis yang diajukan, maka model yang digunakan adalah model regresi linear berganda.

Data penelitian yang digunakan dalam penelitian ini seluruhnya merupakan data skunder yang diperoleh melalui proses pengolahan dari instansi yang terikat dengan penelitian. Data di peroleh dari laporan yang dipublikasikan Badan Pusat Statistika. Untuk mendeskripsikan dan penguji pengaruh penelitian ini menggunakan data IPM, Laju pertumbuhan PDRB, dan Tingkat Pengangguran Terbuka pada tahun 2011-2019. Adapun deskripsi data-data dari tiap-tiap variabel yang digunakan dalam penelitian ini.

Tabel 1. Perkembangan IPM, PDRB, dan TPT

\begin{tabular}{llll}
\hline Tahun & IPM (\%) & $\begin{array}{l}\text { PDRB } \\
(\%)\end{array}$ & $\begin{array}{l}\text { TPT } \\
(\%)\end{array}$ \\
\hline 2011 & 65,77 & 6,57 & 5,78 \\
2012 & 66,18 & 6,45 & 5,98 \\
2013 & 67,18 & 5,61 & 7,1 \\
2014 & 68,00 & 5,12 & 6,6 \\
2015 & 68,53 & 5,03 & 8,02
\end{tabular}


ISSN : 2721-7876

\section{Gamma-Pi: Jurnal Matematika dan Terapan}

Volume 3 Nomor 2 Desember 2021

\begin{tabular}{llll}
2016 & 69,13 & 4,98 & 6,37 \\
2017 & 69,82 & 5,05 & 3,57 \\
2018 & 70,27 & 5,02 & 5,13 \\
2019 & 70,76 & 5,07 & 5,56 \\
\hline
\end{tabular}

\section{HASIL DAN PEMBAHASAN}

\subsection{Uji Asumsi Klasik}

\section{a. Uji Normalitas}

Pengujian ini dilakukan untuk melihat normal atau tidaknya data yang di analisis. Untuk melihat data terdistribusi normal atau tidak dengan menggunakan Normal QQ Plot. Titik-titk disekitar garis adalah keadaan data yang diuji. Jika kebanyakan titik-titik berada sangat dekat dengan garis atau bahkan menempel pada garis, maka data berdistribusi normal.

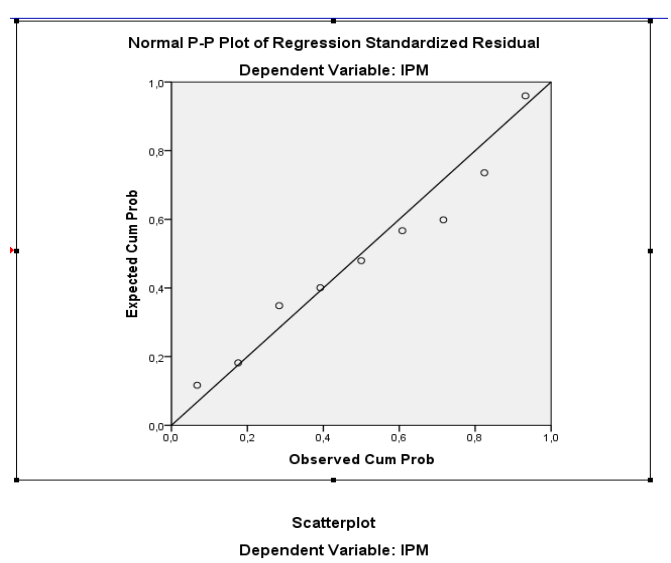

Gambar 1. Uji normalitas mengunakan SPSS

Berdasarkan 1 gambar dapat disimpulkan bahwa distribusi data pada variabel penelitian berdistribusi normal. Karena data menyebar disekitar diagonal dan mengikuti arah garis diagonal.

\section{b. Uji Multikolinearitas}

Uji ini bertujuan untuk mengkaji apakah pada model regresi ditemukan adanya korelasi antar variabel independen. Jika terjadi korelasi, maka terdapat mulitikolinearitas dimana model regresi yang baik seharusnya tidak terjadi korelasi diantara variabel independen. Keadaan ini hanya terjadi pada regresi linier berganda, karena jumlah variabel bebasnya lebih dari satu. Apabila hubungan di antara variabel bebas yang satu dengan yang lain kurang dari 10, maka di pastikan tidak terjadi gejala multikolinearitas.

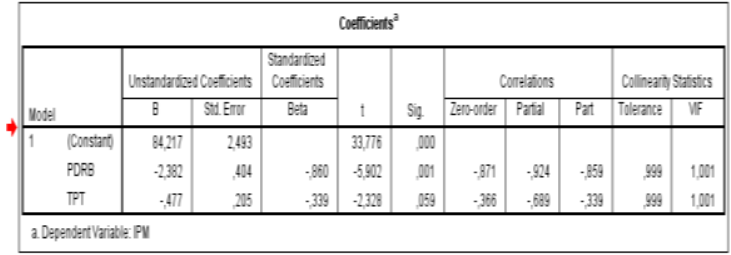

Gambar 2 Hasil uji multikolinearitas

Multikolinearitas terjadi jika nilai tolerance sama dengan atau kecil dari 0,01 dan nilai VIF itu sama dengan lebih besar dari 10 dan multikolinearitas tidak terjadi jika nilai tolerance sama dengan besar 0,01 dan nilai VIF sama dengan kecil dari 10. Maka berdasarkan gambar 2 dapat disimpulkan bahwa tidak terjadi gejala multikolinearitas.

\section{c. Uji Autokorelasi}

Uji Autokorelasi bertujuan untuk menguji apakah dalam satu model regresi linear ada korelasi antara kesalahan pengganggu (residual) pada periode $\mathrm{t}$ dengan kesalahan pada periode $\mathrm{t}-1$ sebelumnya. Autokorelasi terjadi jika nilai Durbin-Watson tidak berada diantara du sampai dengan 4-du.

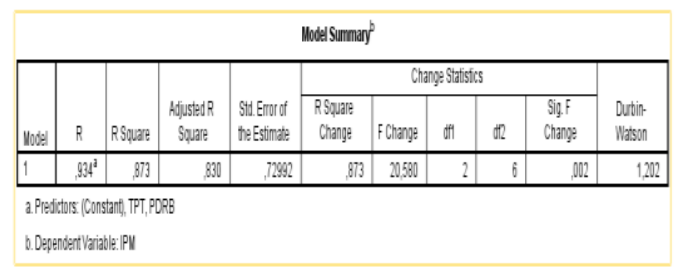

Gambar 3 Hasil Uji Autokorelasi

Berdasarkan Gambar 3 nilai DurbinWatson berada diantara du sampai 4-du berarti tidak terjadi autokorelasi.

\section{d. Uji Heteroskedastisitas}

Uji heteroskedastisitas bertujuan untuk mengetahui ada atau tidaknya penyimpangan asumsi klasik. Heteroskedastisitas yaitu adanya ketidaksamaan varian dari residual untuk semua pengamatan model regresi. Kriteria yang harus di terpenuhi dalam model regresi ada tidak adanya gejala heteroskadastisitas Adapun hasil uji heteroskedastisitas sebagai berikut : 


\section{Gamma-Pi: Jurnal Matematika dan Terapan}

Volume 3 Nomor 2 Desember 2021

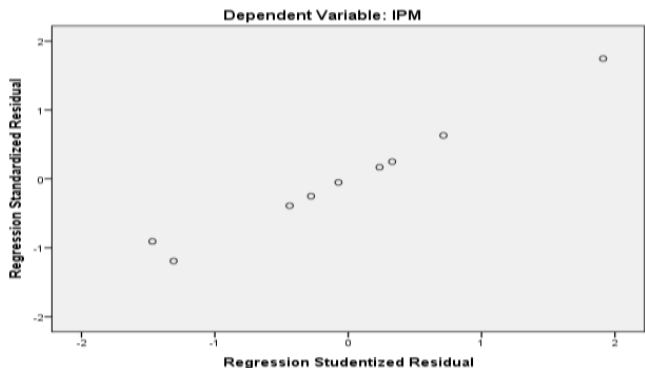

Gambar 4 scatterplot

Berdasarkan scatterplot terjadinya heteroskedastisitas jika scatterplot pada pola tertentu seperti titik-titik yang pada membentuk pola teratur, bergelombang, menyempit dan melebar. Tidak terjadi heteroskedastisitas pada scatterplot tidak ada pola yang jelas serta titik menyebar diatas dan dibawah angka nol pada sumbu Y.

Berdasarkan gambar 4 dapat disimpulkan bahwa tidak terjadi heteroskedastisitas pada tidak terjadi gejala heteroskedastisitas dalam model penelitian. Karena tidak terdapat titik yag menyebar diatas dan dibawah angka nol pada sumbu Y.

\subsection{Uji Hipotesis}

Untuk menjawab permasalahan yang ada pada penelitian ini perlu dilakukan analisis statistic terhadap data yang telah diperoleh. Analisis statistik yang digunakan dalam penelitian ini adalah analisis regresi linear berganda.

Coefficients $^{\mathrm{a}}$

\begin{tabular}{|c|c|c|c|c|c|c|}
\hline \multirow[b]{2}{*}{ Model } & & \multicolumn{2}{|c|}{ Unstandardized Coefficients } & \multirow{2}{*}{$\begin{array}{c}\begin{array}{c}\text { Standardized } \\
\text { Coefficients }\end{array} \\
\text { Beta } \\
\end{array}$} & \multirow[b]{2}{*}{$t$} & \multirow[b]{2}{*}{ Sig. } \\
\hline & & $B$ & Std. Error & & & \\
\hline 1 & (Constant) & 84,217 & 2,493 & & 33,776 & .000 \\
\hline & PDRB & $-2,382$ &, 404 &,- 860 & $-5,902$ &, 001 \\
\hline & TPT &,- 477 & 205 &,- 339 & $-2,328$ & .059 \\
\hline
\end{tabular}

a. Dependent Variable: IPM

Gambar 5 Uji hipotesis

Berdasarkan hasil estimasi pada tabel 5 di atas diperoleh hasil persamaan estimasinya adalah sebagai berikut: $\mathrm{Y}=84.217-2.382 \mathrm{X}_{1}-0.477 \mathrm{X}_{2}$. Dari hasil tersebut dapat dijelaskan sebagai berikut

1. Jika variabel $X_{1}$ dan $X_{2}$ dianggap konstan adalah sebesar 84,217 menunjukkan bahwa apabila IPM meningkat maka akan meningkatkan PDRB sebesar 84,2 \% dan menurunkan Tingkat Pengangguran Terbuka sebesar $81,6 \%$.

2. Koefisien Regresi PDRB $\left(\mathrm{X}_{1}\right)$ adalah sebesar -2,382 menunjukkan bahwa ketika PDRB naik sebesar $1 \%$ maka IPM akan menurun sebesar $2.38 \%$ dengan asumsi variabel bebas lainnya dalam keadaan konstan. Koefisien regresi negatif maka hal ini semakin besar nilai PDRB maka IPM akan semakin menurun. Disini PDRB memiliki pengaruh signifikan dan negatif terhadap IPM.

3. Koefisien Regresi Tingkat Pengangguran Terbuka $\left(\mathrm{X}_{2}\right)$ adalah sebesar - 0.477 menunjukkan bahwa ketika pengangguran naik sebesar $1 \%$ maka IPM akan menurun sebesar $0.47 \%$ dengan asumsi variabel bebas lainnya dalam keadaan konstan. Koefisien regresi negatif maka hal ini semakin besar nilai tingkat pengangguran maka IPM akan diperoleh semakin menurun. Disini Tingkat Pengangguran Terbuka memiliki pengaruh signifikan dan negatif terhadap IPM.

\section{a. Uji t-statistik}

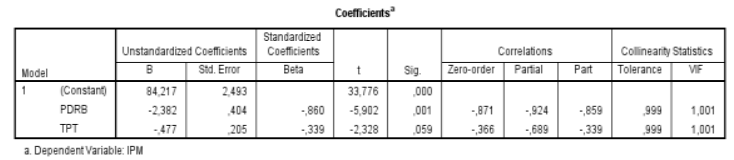

Gambar 6 Uji t-statistik

Untuk mengetahui pengaruh dari masingmasing variabel independen terhadap variabel dependen secara parsial digunakan uji t-statistik, dengan cara melihat nilai t-hitung dibandingkan dengan t-tabel. Derajat bebas pengujian adalah n-k $=25-3=22$ maka diperoleh nilai t-tabel yaitu 1,720. Hasil pengujian dapat dilihat sebagai berikut:

1. Variabel PDRB $\left(\mathrm{X}_{1}\right)$ memiliki nilai t hitung sebesar 84,217 . Nilai ini lebih besar dari $t$ tabel sebesar 1,720 dan sg t (0.000) lebih kecil dari 0,05 , sehingga pengujian hipotesis penelitian untuk $\mathrm{H}_{\mathrm{a}}$ diterima dan $\mathrm{H}_{0}$ ditolak. Hal ini menjelaskan bahwa secara parsial PDRB berpengaruh signifikan terhadap IPM.

2. Variabel Tingkat Pengangguran Terbuka $\left(\mathrm{X}_{2}\right)$ memiliki nilai thitung sebesar 1,725 . Nilai ini lebih besar dari t tabel sebesar 1,720 dan sig t $(0,000)$ lebih kecil dari 0,05 , sehingga pengujian hipotesis penelitian untuk $\mathrm{H}_{\mathrm{a}}$ diterima dan $\mathrm{H}_{0}$ ditolak. Hal ini menjelaskan bahwa Tingkat Pengangguran Terbuka berpengaruh signifikan terhadap IPM 


\section{Gamma-Pi: Jurnal Matematika dan Terapan}

Volume 3 Nomor 2 Desember 2021

\section{b. Uji F Statistik}

\begin{tabular}{|c|c|c|c|c|c|c|}
\hline \multicolumn{7}{|c|}{ ANOVA $^{a}$} \\
\hline \multicolumn{2}{|c|}{ Model } & $\begin{array}{l}\text { Sum of } \\
\text { Squares }\end{array}$ & df & Mean Square & $\mathrm{F}$ & Sig. \\
\hline \multirow[t]{3}{*}{1} & $\begin{array}{l}\text { Regression } \\
\end{array}$ & 21,930 & 2 & 10,965 & 20,580 & $.002^{b}$ \\
\hline & Residual & 3,197 & 6 & .533 & & \\
\hline & Total & 25,126 & 8 & & & \\
\hline
\end{tabular}

Gambar 7 Uji F Statistik

Uji F digunakan untuk mengetahui apakah variabel bebas berpengaruh nyata atau tidak secara bersama-sama terhadap variabel terikat dengan membandingkan nilai F-hitung dan F-tabel, F-tabel dengan nilai df $1=\mathrm{k} 1=3-1=2$ dan df $2=\mathrm{n}-\mathrm{k}=$ 25-3 = 22 maka F-tabelnya adalah 4,52.

Kriteria: $\mathrm{H}_{0}$ diterima apabila $\mathrm{Sig}(\mathrm{F}$-statistik) $>\alpha$ $(0,05)$

$$
\mathrm{H}_{\mathrm{a}} \text { diterima apabila Sig (F-statistik) }<\alpha
$$

Sig (F-statistik) : 0,02

Berdasarkan hasil perhitungan menggunakan spss dapat diketahui bahwa Fstatistik adalah 20,580. Nilai Sig F statistic 0.02 lebih kecil dari tingkat signifikan 0,05. Sehingga pengujian hipotesis $\mathrm{Ha}$ diterima dan $\mathrm{H} 0$ ditolak. Hal ini menjelaskan bahwa secara simultan PDRB $\left(\mathrm{X}_{1}\right)$ dan Tingkat Pengangguran Terbuka $\left(\mathrm{X}_{2}\right)$ berpengaruh signifikan terhadap IPM (IPM) di Kabupaten Langkat.

\section{KESIMPULAN}

Berdasarkan hasil pembahasan dan analisis data penelitian tentang pengaruh PDRB dan Tingkat Pengangguran Terbuka terhadap IPM di Kabupaten Langkat, maka dapat ditarik kesimpulan sebagai berikut :

1. Variabel Produk Domestik Regional Bruto (PDRB) berpengaruh negatif dan signifikan terhadap IPM di Kabupaten Langkat.

2. Variabel Tingkat Pengangguran Terbuka berpengaruh negatif dan signifikan terhadap IPM (IPM) di Kabupaten Langkat.

3. Variabel Produk Domestik Regioanl Bruto (PDRB) dan Tingkat Pengangguran Terbuka secara bersama-sama berpengaruh signifikan terhadap IPM di Kabupaten Langkat. Sehingga dapat dikatakan bahwa PDRB salah satu penyebab kenaikan IPM di Kabupaten Langkat. Dan tingkat pengangguran terbuka adalah salah satu penyebab menurunnya IPM di Kabupaten Langkat.

\section{REFERENSI}

D, Jani. 2012. Statistik Dekriptif dan Regresi Linier Berganda dengan SPSS. Semarang: Semarang University Press.

Imsar. 2018. Analisis Tingkat Pengangguran Di Indonesia 1989-2016. FEBI UIN-SU Press.

Kairupan, P. 2013. Produk Domestik Regional Bruto (PDRB), Inflasi dan Belanja Daerah Pengaruhnya terhadap Kesempatan Kerja. Sulawesi Utara.

Nirmala. 2012. Statistik Dekriptif dan Regresi Linier Berganda dengan SPSS. Semarang: Semarang University Press.

Nurcholis, Muhammad. 2014. Analisis Pengaruh Pertumbuhan Ekonomi, Upah Minimum dan Indeks Pembangunan Manusia terhadap Tingkat Pengangguran. Jawa Timur.

Saputra. 2011. Analisis Pengaruh Jumlah Penduduk, PDRB, IPM, Pengangguran Terhadap Tingkat Kemiskinan di Kabupaten Kota Jawa Tengah. Semarang: Universitas Diponegoro. 